\title{
SCARF JOINTS IN GLUED LAMINATED TIMBER OF PARICÁ
}

\author{
Rodrigo Figueiredo Terezo ${ }^{1 *}$, Talitha Oliveira Rosa ${ }^{2}$, Francisco Raphael Cabral Furtado ${ }^{3}$, Camilla Gabriela Melo \\ Ampessan ${ }^{1}$, Alexsandro Bayestorff da Cunha ${ }^{1}$, Ângela do Valle ${ }^{4}$ \\ ${ }^{1 *}$ Universidade do Estado de Santa Catarina, Centro de Ciências Agroveterinárias, Departamento de Engenharia Florestal, Lages, Santa \\ Catarina, Brasil - e-mail (*rodrigo.terezo@udesc.br; camila.ampessan@gmail.com alexsandro.cunha@udesc.br) \\ ${ }^{2}$ Universidade Federal do Paraná, Programa de Pós-Graduação em Engenharia Florestal, Curitiba, Paraná, Brasil (rosa.talitha@gmail.com) \\ ${ }^{3}$ Instituto Federal do Rio Grande do Sul, Vacaria, Rio Grande do Sul, Brasil (franciscofur@ gmail.com) \\ ${ }^{4}$ Universidade Federal de Santa Catarina, Departamento de Engenharia Civil, Florianópolis, Santa Catarina, Brasil (angela.valle@ufsc.br)
}

Received for publication: 25/03/2020 - Accepted for publications: 22/07/2020

\begin{abstract}
Resumo
Emendas biseladas em madeira tropical de paricá. A Madeira Lamelada Colada (MLC) é formada pela união de lamelas de madeira coladas paralelamente umas às outras. Maiores dimensões longitudinais da MLC podem ser obtidas ao colar o topo de duas lamelas. A colagem de topo pode ser realizada pelo uso de uma emenda biselada que possui forma de cunha. Contudo, as emendas apresentam uma descontinuidade da madeira, sendo áreas consideras suceptíveis a ruptura. Deste modo, os objetivos foram avaliar quatro inclinações (1:6; 1:8; $1: 10$ e 1:12) em emendas biseladas na madeira de Schizolobium parahyba var. amazonicum para uso estrutural; e vigas de madeira lamelada colada - MLC produzidas com a emenda de melhor desempenho pelo módulo de elasticidade - Ew teórico e analítico. Todas as lamelas utilizadas para a confecção dos corpos de prova foram classificadas visualmente de modo a estarem limpas de defeitos, como nós. Os corpos de prova foram adaptados para o teste de flexão a quatro pontos e tração paralela às fibras de acordo com a NBR 7190 (1997). A inclinação 1:12 apresentou as melhores resistências, enquanto a inclinação 1:6 apresentou resultados inferiores quando comparada com o testemunho. As vigas de 5 x 9,5 x $220 \mathrm{~cm}$ compostas com emendas com inclinação 1:12, apresentaram valores de Ew estatisticamente iguais às vigas sem emendas. A emenda biselada apresentou ser uma alternativa para o uso em vigas de MLC de paricá, por apresentar resistência e rigidez compatível com vigas sem emenda.

Palavras-chave: estruturas de madeira; emenda longitudinal; florestas plantadas tropicais.
\end{abstract}

\begin{abstract}
Glued Laminated Timber (GLULAM) is manufactured by joining wood lamellae glued in parallel to each other. GLULAM with larger longitudinal dimensions can be obtained by gluing the tops of two wood lamellae. The gluing of the tops can be done using wedge-shaped scarf joints. However, the joints produce a discontinuity in the wood, being areas considered as susceptible to rupture. In this way, the objectives were to evaluate four slopes $(1: 6 ; 1: 8 ; 1: 10$ and $1: 12)$ in scarf joints of Schizolobium parahyba var. amazonicum timber for use with structural purposes; and glued laminated timber beams - GLULAM manufactured with the scarf joint with the best performance by the modulus of elasticity - MOE (theoretical and analytical MOE values). Each laminated timber used to produce the test specimens was classified by visual inspection that aimed at the absence of defects, such as knots. The test specimens were adapted to the four-point static bending test and to the tensile strength test in parallel to the grain direction, in accordance to the NBR 7190 (1997). The slope of 1:12 showed the best results, while the slope of 1:6 presented the lowest results when compared with the control. The beams of $5 \times 9.5 \times 220 \mathrm{~cm}$, composed of joints with slopes of 1:12, showed MOE values statistically equal to those of beams without joints. The scarf joint proved to be an alternative for use in glulam beams of paricá, as it presents stiffness and strength comparable with those of beams without a joint.
\end{abstract}

Keywords: timber structures; longitudinal joints; tropical planted forests.

\section{INTRODUCTION}

Wood structural elements for use in Glued Laminated Timber - GLULAM are mostly from forests planted with exotic species, mainly the Eucalyptus and Pinus genera. In Brazil, most of the glulam elements are made from Eucalyptus, since species of this genus show a high structural grade.

Although the country has an area of 7.84 million hectares of eucalyptus and pine forests, only $4 \%$ of these areas are managed aiming at solid wood as a final product. In addition to the forests of exotic species, the country has an area of approximately 590 thousand hectares of forests planted with native species, among them the paricá (Schizolobium parahyba var. amazonicum) (IBA, 2017). This species is present in reforestation of homogeneous or mixed species plantations for commercial exploitation. 
Paricá has high productivity in terms of wood volume produced per hectare, with increments of up to $35 \mathrm{~m}^{3} \cdot \mathrm{ha}^{-1}$.year ${ }^{-1}$, with plantations widely spread in the states of Pará and Mato Grosso (TEREZO; SZÜCS, 2010). Its annual increment rises higher than that of the genus Pinus (25 to $30 \mathrm{~m}^{3} \cdot \mathrm{ha}^{-1}$.year $\mathrm{yr}^{-1}$ ) and that of the genus Tectona grandis (15 to $20 \mathrm{~m}^{3} \cdot \mathrm{ha}^{-1}$.year ${ }^{-1}$ ) and, solely the genus Eucalyptus can reach $50 \mathrm{~m}^{3} \cdot \mathrm{ha}^{-1}$. $\mathrm{year}^{-1}$. It is important to note that there is no program for the genetic improvement of paricá, unlike other species used in large-scale plantations in Brazil (SILVA et al., 2016).

Paricá wood has a density ranging from 0.30 to $0.41 \mathrm{~g} \cdot \mathrm{cm}^{-3}$ (ALMEIDA et al., 2011; ROSA et al., 2019). It has no knots in the first logs (MELO et al., 2014) and recent research has stated that this species can be used in structural products because its wood is classified as C-20 according to the Brazilian Standard NBR 7190 (1997), as in Glued Laminated Timber - GLULAM (TEREZO; SZÜCS, 2010; ALMEIDA et al., 2011; TEREZO et al., 2015).

The total length of the wood lamellae used in glulam is limited depending on the tree. One way of obtaining elements with large longitudinal dimensions is by bonding the splice joints of two wood lamellae. These joints can be of the butt, finger or scarf type. However, as the joints cause a discontinuity in the "wood" material, they are areas susceptible to rupture and considered weak regions.

Since the splice region has a reduced resistance when compared to the wood lamella without joints (KIMIAEIFAR et al., 2012), these is considered as one of the most important characteristics in the glulam product, as they are directly associated to the strength and stiffness of the material. Thus, when bonding two wood lamellae, higher strength levels should be sought than that of a laminated timber sawn without joints.

The strength of glulam is linked to the type of adhesive and joint, in the case of scarf joints, the scarf slope is the most important factor in terms of strength (NASCIMENTO et al., 2001). The slope allows this joint to be as effective as other types of splice joints, also ensuring easy production, as it does not require sophisticated equipment. Scarf joint is used in the restoration of historic buildings, since it is aesthetically pleasing and allows to maintain the load-bearing capacity of the beam (ARCISZEWSKA-KĘDZIOR et al., 2016), making it an excellent alternative for the manufacture of glulam.

Considering the potential use of scarf joints, the objectives of this study were to analyze scarf joints glued with different slopes in tropical paricá wood (Schizolobium parahyba var. amazonicum Huber ex. Ducke), determining the best scarf slope by tensile and bending strength tests; and evaluate glued-laminated timber beams produced with the joint with the best performance.

\section{MATERIAL AND METHODS}

The paricá wood used in the present study came from planted forests in the Northeast region of the State of Pará. In order to recreate the conditions found in the industry, that is, material from different sources with respect to age, all timber used in this study was chosen randomly from a lot of wood with 4 different ages.

Trees were aged 6,10,19 and 28 years. Trees at ages of 6 and 10 years were planted in the municipality of Aurora do Pará ( $2^{\circ} 10^{\prime} 27.5^{\prime \prime} \mathrm{S}$ latitude and $47^{\circ} 32^{\prime} 42.0^{\prime \prime} \mathrm{W}$ longitude), and the trees at ages of 19 and 28 years in the municipality of Tomé-Açu ( $2^{\circ} 23^{\prime} 42.7^{\prime \prime} \mathrm{S}$ latitude and $48^{\circ} 08^{\prime} 43.4^{\prime \prime} \mathrm{W}$ longitude).

\section{Test specimens planning}

The wood was sawn in timber boards of $8 \times 12 \times 300 \mathrm{~cm}$, kiln-dried until reaching an equilibrium moisture content of $12 \%$, in the city of Belém - PA. Subsequently, they were transported to the Laboratory of Wood Technology of the State University of Santa Catarina, in the municipality of Lages - SC.

The material was selected on a random basis. To assess the slope angle, 20 test specimens (TS) were separated for each of the treatments: control (C), and for the scarf joints with different cutting angles with slopes of $1: 12 ; 1: 10 ; 1: 8$ and 1:6, totaling 100 test specimens (Table 1).

FLORESTA, Curitiba, PR, v. 51, n. 3, p. 713-720, jul/set 2021. 
Table 1. Experimental plan for the assessment of scarf joints in test specimens.

Tabela 1. Plano experimental para avaliação das emendas biseladas em corpos de prova.

\begin{tabular}{|c|c|c|}
\hline & \multicolumn{2}{|c|}{$\begin{array}{c}\text { Number of Test } \\
\text { specimens }\end{array}$} \\
\hline & Bending & Tensile \\
\hline $1: 12$ & 10 & 10 \\
\hline $1: 10$ & 10 & 10 \\
\hline 1:8 & 10 & 10 \\
\hline 1:6 & 10 & 10 \\
\hline Control (without joints) & 10 & 10 \\
\hline
\end{tabular}

Figure 1 shows the diagram of the slopes used to produce the scarf joints. The slope depends on the height (thickness) of the test specimen. For each $1 \mathrm{~cm}$ height (h) there is a length (1), resulting in a cutting angle.

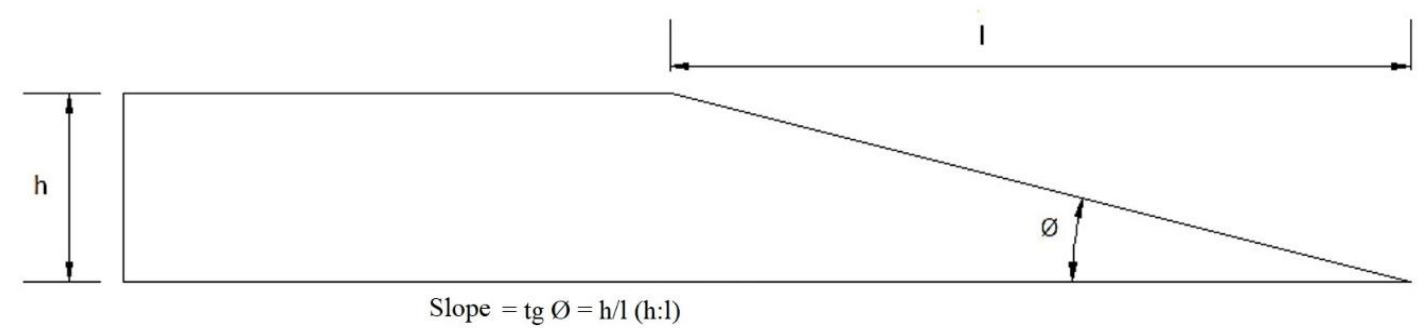

Figure 1. Slopes of scarf joints as a function of thickness.

Figura 1. Inclinações das emendas biseladas em função da espessura.

The test specimens, with dimensions of $1.5 \times 3.0 \times 45.0 \mathrm{~cm}$, were marked on both ends and then cut in half to obtain the joints. The cut was made using a template attached to a circular saw. Next, the test specimens were placed in a temperature-controlled room at approximately $25{ }^{\circ} \mathrm{C}$ and $65 \%$ humidity to standardize the moisture content present in the wood.

Before gluing, a jet of compressed air was blasted on all joints in order to avoid contamination and future bonding problems due to sawing waste. For the bonding of the joints, a polyurethane-based adhesive, TekBond Pur commercial brand was used. The adhesive was applied on both sides of the joints, with a weight of $250 \mathrm{~g} \cdot \mathrm{m}^{-2}$, controlled using a scale.

The splice joints were joined tightly together using a manual press for a period of 24 hours. After bonding, the TSs were again placed in a temperature-controlled environment to finish the curing of the adhesive. Next, mechanical assays were performed to assess the strength of the treatments.

The tensile strength test in parallel to the fiber orientation and the four-point static bending test (Figure 2) were performed using a Universal Emic machine, with a 30 ton load capacity, and the load application speed was determined in accordance with the Brazilian standard ABNT - NBR 7190 (1997), until the occurrence of rupture. 


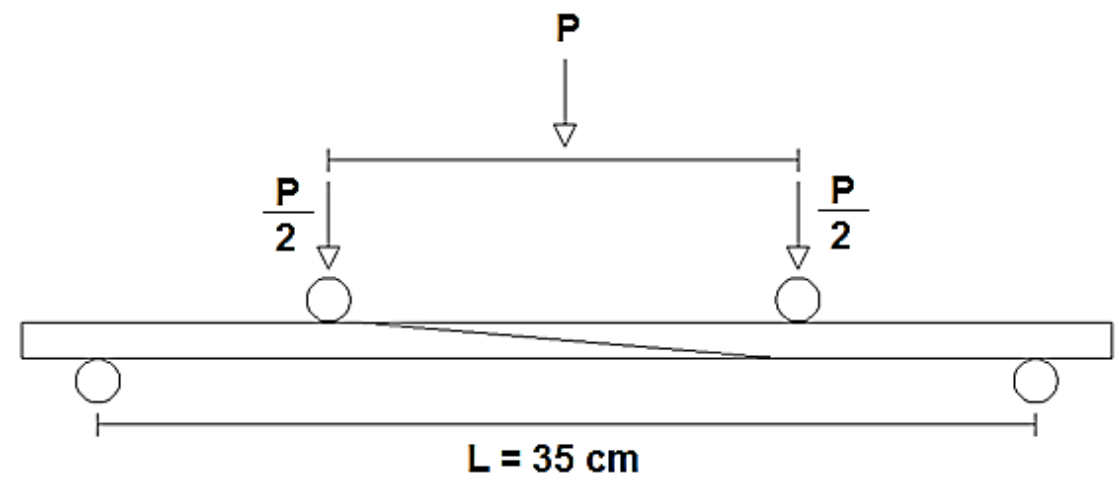

Figure 2. Diagram of the four-point static bending test on test specimens with scarf joints; where $\mathrm{P}$ is the load applied, measured in Newtons, and L is the length of the span between the supports.

Figura 2. Esquema do ensaio de flexão estática à quatro pontos em corpos de prova com emendas biseladas; sendo que P é a força aplicada em Newtons e L é o comprimento do vão entre os apoios.

Of the twenty specimens in each treatment, half were subjected to the bending test and half to the tensile strength test in parallel to the fiber orientation. After, the fractures in the joints were visually assessed, and they were classified as: $100 \%$ rupture in the wood; $25 \%$ rupture in the glue line; $50 \%$ in the glue line; $75 \%$ and $100 \%$ in the glue line.

The results were also evaluated using statistical tests of normality (Shapiro-Wilk), homogeneity (Bartlet) and comparison of means (Scott-Knott), to assess the effect of the scarf slope on the strength of the test specimens of paricá. All tests were performed with a probability level set at $5 \%$.

\section{Manufacture of GLULAM beams}

The wood lamellae used were free of defects, according to classification by visual inspection (NBR $7190,1997)$, and with dimensions of $2.5 \times 6.0 \times 230 \mathrm{~cm}$. For the bonding of the beams, all wood lamellae were mechanically classified, obtaining the Longitudinal Modulus of Elasticity - MOE (ASTM D 4761, 2013) by the three-point bending test. Previously, bending tests were performed on five wood lamellae to define a maximum load of $70 \mathrm{~N}$. This previous assay aimed at ensuring that the displacement of the other wood lamellae used in the experiment was always within the elastic zone of the material.

The deflection measurement of the wood lamellae was performed manually, in order to estimate the displacement at the central point on the span, whose total length was $220 \mathrm{~cm}$. A $70 \mathrm{~N}$ load was applied on the same central point. Initially, the position of the wood lamella before application of the load was read directly using a graduated ruler; then, the displacement of the wood lamella was read after application of the load on the center of the span. The procedure was performed on both sides of the wood lamellae in the flatwise position (lower inertia). The MOE value was calculated using the expression (1).

$$
E_{W}=\frac{F L^{3}}{48 D_{x} I} \quad \text { Equação } 1
$$

Where: $\mathrm{E}_{\mathrm{W}}=$ Modulus of Elasticity $(\mathrm{MOE})$ in N/mm²; $F=$ Load applied on the center of the span in N; $L=$ span between the supports in $\mathrm{mm} ; D x=$ Mean squared displacement of the wood lamella in $\mathrm{mm} ; I=$ Moment of Inertia of the wood lamella in $\mathrm{cm} \mathrm{mm}^{4}$.

For the manufacture of glulam beams, the MOE values obtained in the previous test were ranked from the highest to the lowest. The wood lamella with the highest MOE value was positioned in the zone of maximum strength, and the second wood lamella with the highest MOE was positioned in the zone of maximum compression. The wood lamellae with the lowest MOE values were positioned in the central (neutral) areas of the beams. This assignment occurred successively for all beams composed of 4 wood lamellae.

In total, 2 test beam specimens were assembled for the calibration of the test, 3 beams without scarf joints and three beams with scarf joints. The angle of the scarf joint was chosen according to the preliminary tensile and bending strength tests of the TS's. As the results showed a greater efficiency of the angle of 1:12, this was used as a basic parameter in the manufacture of the scarf joints for the assessment of the beams.

The wood lamellae were cut using a circular saw and a template to obtain a slope of 1:12. After being cut, the wood lamellae were flattened and the sawing waste was removed so that the gluing could be carried out.

FLORESTA, Curitiba, PR, v. 51, n. 3, p. 713-720, jul/set 2021. 
The polyurethane-based adhesive was applied with a weight of $250 \mathrm{~g} \cdot \mathrm{m}^{-2}$ and the gluing was carried out in a manual press for 24 hours, with a pressure of between 1 and $1.4 \mathrm{MPa}$. After being glued, the beams were flattened on their 4 faces to remove glue residues and, subsequently subjected to the static bending test with two loading points and two support points for strength assessment.

\section{Testing of GLULAM beams}

The beams were tested in accordance with NBR 7190 Standards (1997) for the static bending test. Next, two beams were subjected to loads until the rupture happens, to obtain the modulus of rupture. For this purpose, a universal testing machine, with a capacity of 20 ton, was used in the Laboratory of Experimentation in Structures (LEE), of the Civil Engineering department, at the Federal University of Santa Catarina - UFSC.

It was a four-point static bending test, with a $180 \mathrm{~cm}$ span (L) between supports and a distance of $70 \mathrm{~cm}$ between load applicators. Deformations were read using displacement transducers of the data acquisition equipment, HBM Spider.

Previously, tests were carried out until rupture happens on two test beam specimens to define the elastic zone.

To assess the distribution of the position of the scarf joints in the beam, tests were performed so that the maximum load applied was within the elastic zone of the material. On the first side of the tested beam (Side 1), the lamella without joints was positioned in the upper central part of the beam, and on the second side (Side 2) the lamella was positioned in the lower central part. The configuration of the scarf joints, as well as their respective positions, are shown in Figure 3.

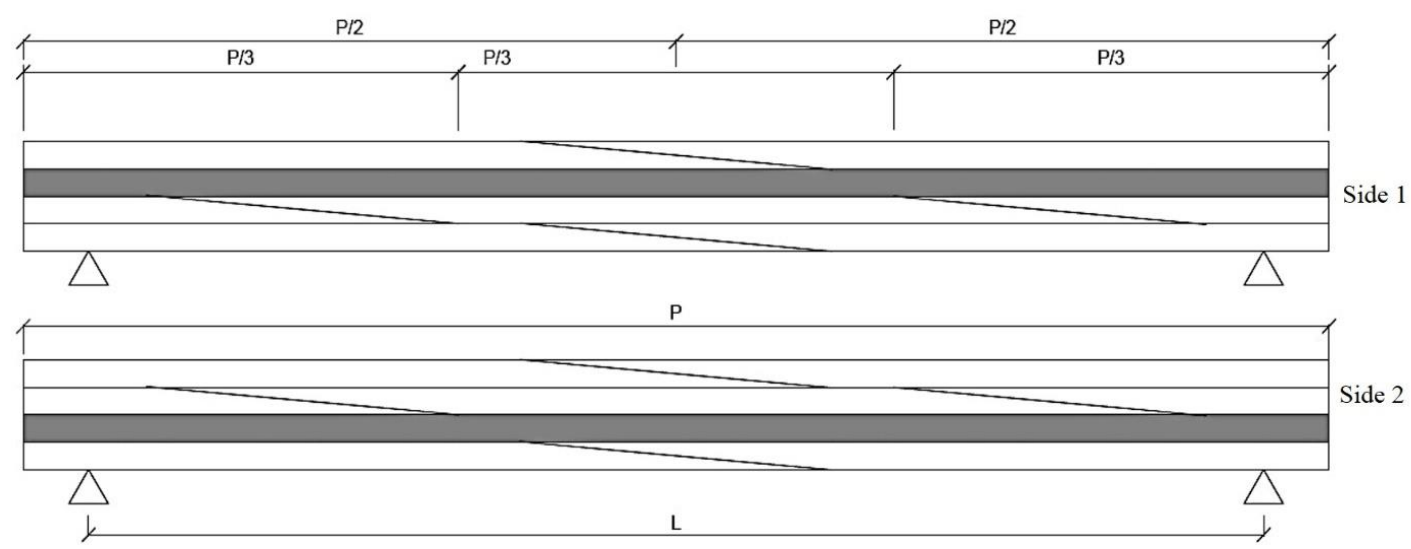

Figure 3. Distribution of scarf joints within glulam beams, where $\mathrm{P}=220 \mathrm{~cm}$ and $\mathrm{L}=180 \mathrm{~cm}$.

Figura 3. Distribuição de emendas biseladas dentro de vigas de MLC, sendo que $P=220 \mathrm{~cm}$ e L= $180 \mathrm{~cm}$.

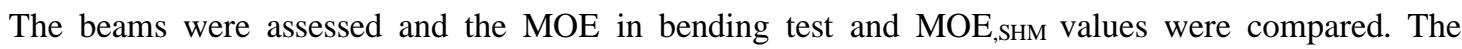
theoretical calculation was performed using the Sectional Homogenization Method - SHM, to determine the possibility of using the method for beams of paricá with scarf joints, according to the methodology proposed by Rosa et al., (2019). This is a method for analytically estimating the final modulus of elasticity using mathematical expressions.

\section{RESULTS}

The normality test of the bending strength confirmed the normal distribution of the data, and all test specimens used in the bending strength test proved to be normal, with a p-value of 0.7642 by the Shapiro-Wilk test. The values of the tensile strength test in parallel to the fibers showed a normal distribution, with a p-value of 0.663 , after statistical treatment of log-transformed data.

Figure 4 shows the data of the bending test and the tensile strength test in parallel to the fibers evaluated by comparison of means, according to the Scott-Knott's test. In the bending strength test, the slopes of 1:12 and 1:8 showed results statistically equal to those of the control. Regarding the results obtained by the tensile strength test in parallel to the fibers, it is observed that the results of none of the treatments with scarf joints were statistically equal to those of the control. 


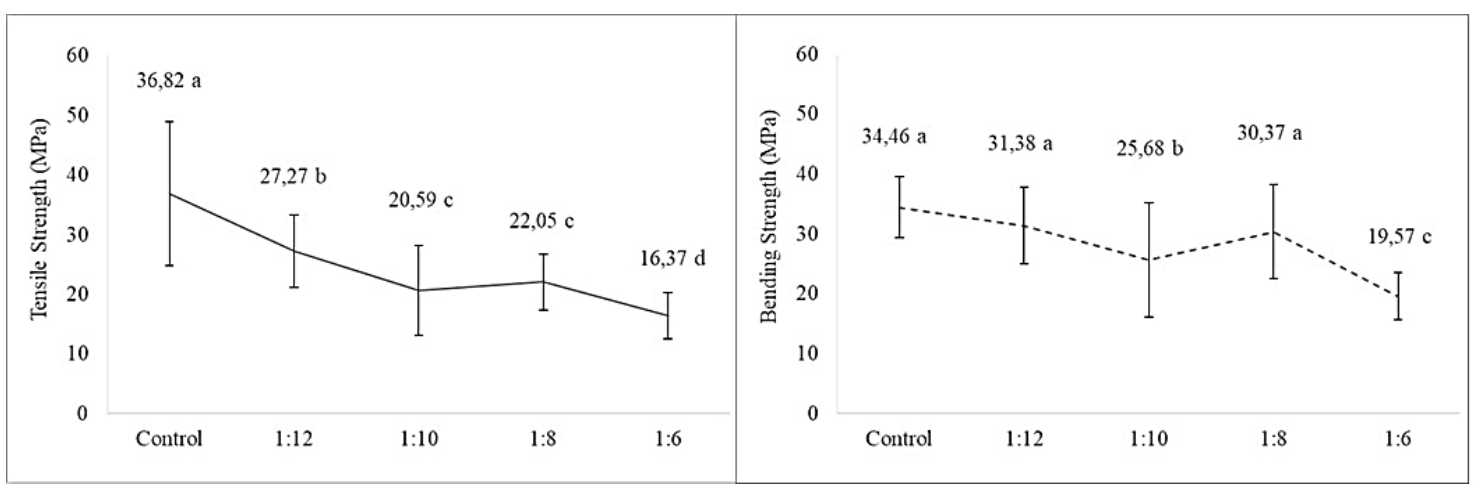

Figure 4. Mean values of the tensile strength test in parallel to the fibers and the static bending strength of the control and the treatments with scarf joints with different slopes.

Figura 4. Valores médios de resistência à tração paralela às fibras e à flexão estática dos tratamentos testemunha e com emendas biseladas em diferentes inclinações.

Ruptures in the different treatments in the tensile and bending strength tests occurred: in 1:6, 80\% and $90 \%$ in the glue line; in 1:8, 90\% broke in the wood in both tests; $1: 10,80 \%$ and $90 \%$ broke in the wood; and in $1: 12,80 \%$ and $100 \%$ broke in the wood, respectively. Figure 5 shows some examples of ruptures occurred in the bending test in different bevel angles.

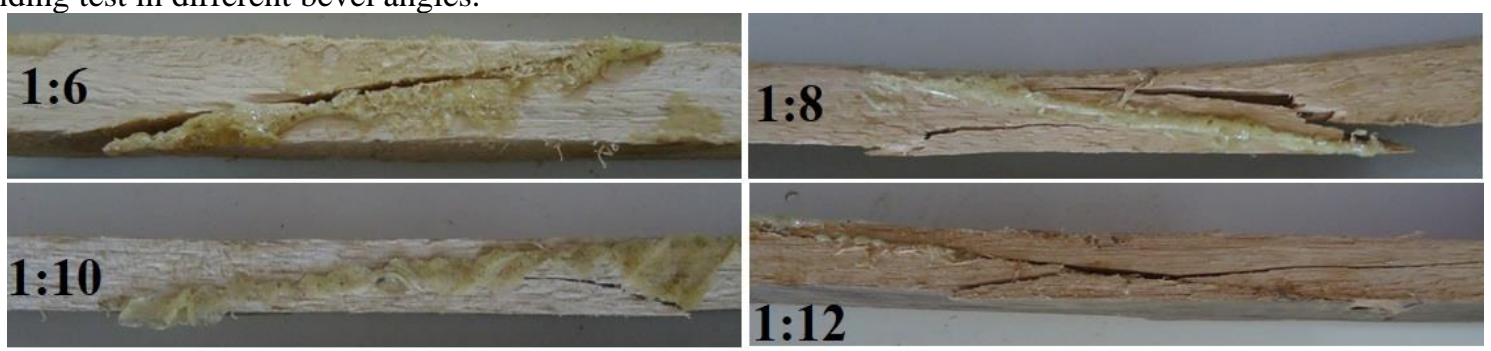

Figure 5. Examples of ruptures in the four-point bending test at different cutting angles of scarf joints.

Figura 5. Exemplos de ruptura no teste flexão a quatro pontos em diferentes ângulos de corte das emendas biseladas.

Regarding the assessment of the glulam beams composed of wood lamellae with scarf joints, Table 2 shows that there were no statistical differences between the MOE values obtained by the static bending test and

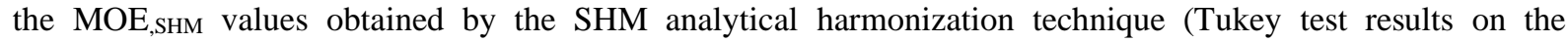
column). The test of means between the MOE, bending and MOE, sHM values (Tukey test results on the line) indicated statistical differences only between beams with scarf joints on Side 1 position.

Table 2. Modulus of elasticity and SHM of paricá beams with and without scarf joints.

Tabela 2. Módulos de elasticidade teórico e pelo MHS de vigas de paricá com e sem emendas biseladas.

\begin{tabular}{|c|c|c|c|c|c|c|}
\hline $\begin{array}{l}\text { Beam- } \\
\text { scarf joint } \\
\text { position }\end{array}$ & $\begin{array}{l}\text { MOE,bending } \\
\text { (MPa) }\end{array}$ & $\delta t(\mathrm{~mm})$ & $\begin{array}{c}\text { MOE, SHM } \\
\text { (MPa) }\end{array}$ & $\begin{array}{c}\boldsymbol{\delta} \mathbf{v} \\
(\mathbf{m m})\end{array}$ & $\begin{array}{c}\text { Abs. Dif. } \delta \\
(\delta \mathrm{t}-\delta \mathrm{v})\end{array}$ & p-value \\
\hline $1-1$ & 19.225 & 6.91 & 20.437 & 5.62 & 1.29 & \\
\hline $2-1$ & 16.046 & 12.35 & 22.500 & 8.13 & 4.22 & \\
\hline $\begin{array}{c}\text { Mean } \\
\text { c.v }\end{array}$ & $\begin{array}{c}17.635 \mathrm{aA} \\
12.75\end{array}$ & & $\begin{array}{c}21.468 \mathrm{aB} \\
6.80\end{array}$ & & & 0.0248 \\
\hline $1-2$ & 25.998 & 4.05 & 22.548 & 3.69 & 0.36 & \\
\hline $2-2$ & 20.986 & 8.15 & 22.576 & 4.97 & 3.18 & \\
\hline $\begin{array}{c}\text { Mean } \\
\text { c.v }\end{array}$ & $\begin{array}{c}23.492 \mathrm{aA} \\
15.09\end{array}$ & & $\begin{array}{c}22.567 \mathrm{aA} \\
0.09\end{array}$ & & & 0.5560 \\
\hline 3-control & 15.765 & 18.71 & 16.079 & 18.45 & 0.26 & \\
\hline 4-control & 20.561 & 22.68 & 21.204 & 22.28 & 0.4 & \\
\hline 5-control & 20.103 & 14.81 & 18.804 & 15.21 & -0.4 & \\
\hline $\begin{array}{c}\text { Mean } \\
\text { c.v }\end{array}$ & $\begin{array}{c}18.809 \mathrm{aA} \\
14.07\end{array}$ & & $\begin{array}{c}18.696 \mathrm{aA} \\
13.72\end{array}$ & & & 0.9598 \\
\hline p-value & 0.1973 & & 0.1867 & & & \\
\hline
\end{tabular}

$\mathrm{MOE}_{\text {, bending }}$ - modulus of elasticity in static bending test; $\delta$ t- theoretical maximum arrow; MOE, sHM - modulus of elasticity by SHM; $\delta \mathrm{v}-$ analytical maximum arrow; Abs. Dif. $\delta$ - absolute difference of the maximum arrow; Rel. Dif. $\delta$ - relative difference of the maximum arrow;

FLORESTA, Curitiba, PR, v. 51, n. 3, p. 713-720, jul/set 2021. 
c.v - coefficient of variation in percentage (\%). Equal lowercase letters show no statistically significant differences on the column, and uppercase letters on the line, by the Tukey test, considering $5 \%$ of significance.

Table 3 shows the values of the modulus of rupture of two beams on Side 2 position, taken to rupture. It can be observed that the rupture strength in beam 2 was $21 \%$ higher than in beam 1 . In both beams, ruptures started in the wood, which indicates a good quality of the glued product.

Table 3. Tested beams until rupture.

Tabela 3. Vigas ensaiadas até a ruptura.

\begin{tabular}{cccc}
\hline $\begin{array}{c}\text { Beam- } \\
\text { position }\end{array}$ & $\begin{array}{c}\text { Rupture load } \\
(\mathbf{k N})\end{array}$ & $\begin{array}{c}\text { Bending } \\
\text { strength }(\mathbf{M P a})\end{array}$ & Mode of rupture \\
\hline $\mathbf{1 - 2}$ & 9.85 & 36.54 & $\begin{array}{c}\text { Rupture in the lower lamella starting in the } \\
\text { wood and going to the scarf joint }\end{array}$ \\
\hline $\mathbf{2 - 2}$ & 11.95 & 42.43 & Rupture in the lower lamella of the beam \\
\hline
\end{tabular}

\section{DISCUSSION}

As it can be seen in Figure 4, the greater the slope of the scarf joint, the lower the strength due to the occurrence of a decrease in tensile strength when increasing the cutting angle, according to the means of the results. Strength loss was not observed in beams with scarf joints with lower scarf slopes. However, the treatment with slope of 1:6, which presents the smallest bonding area, showed the lowest strength results in both tests performed.

A higher strength in bevels with lower slopes was also observed by Dajbych et al. (2010), whose study assessed angles ranging from $0^{\circ}$ to $90^{\circ}$, and the results indicated a higher strength in angles with a larger contact area between glue and wood for several commercial European wood species. The same behavior was observed by Nascimento et al. (2001), who tested different levels of pressures on the scarf joints of Pinus $s p$ and Eucalyptus $s p$ woods. They concluded that slopes with a larger bonding area have a higher strength.

As expected, the smaller the angle used for the bonding, the higher the mean strength of the scarf joint. All the slopes studied in the bending test, except the slope of 1:6, presented strength above $82 \%$, according to the value recommended by the German standard DIN 68140 (1971) for finger joints.

According to Herák et al. (2009), wood has a higher strength in the direction of the fibers than in the direction perpendicular to them, as observed in this study, and the levels of strength were higher and comparable with those of solid wood in joints with slopes of 1:8, 1:10 and 1:12, in the bending test. In the tensile strength test, none of these treatments showed strength above $82 \%$, compared to the control in the tensile strength test parallel to the fibers.

The similarity of the results in Table 2 between beams with scarf joints and control beams was expected, since scarf joints with a larger bonding area show better results in terms of increased bonding strength (HERÁK et al., 2009).

Regarding the wood lamellae on Side 1 position, it is observed that the lamella in the lower central part has two scarf joints, followed by a lamella with a central joint positioned below. This region has a greater influence of tensile forces when the beam is subjected to a bending load. Therefore, Side 1 position showed lower MOE values because of a greater fragility of the lower part, and the beam with this configuration has a lower strength, being more susceptible to ruptures. This behavior cannot be predicted by the SHM method, since it considers only the individual modulus of elasticity of the lamellae and their dimensions, without considering discontinued areas of this material.

The results of the modulus of rupture of beams of paricá with scarf joints (Table 3) were similar to those of Almeida et al. (2011), who studied glulam beams of paricá glued with phenol-resorcinol adhesive and wood lamellae assessed by visually inspection as SS (Special Structural Class), whose mean strength was $41 \mathrm{MPa}$. The results of the modulus of rupture were even superior to the results reported by Cunha and Matos (2011), who assessed Pinus elliotti beams with a systematical distribution, classified in a non-destructive mode, and obtained a bending strength of $26 \mathrm{MPa}$.

\section{CONCLUSIONS}

- Wooden bonded scarf joints with smaller angles therefore have a larger bonding area, resulting in a higher strength to tensile and bending loads.

- The simple use of scarf joints with the best performance in tensile and bending tests does not optimize the glulam composite. In its manufacture, both the scarf joints and their distribution/position within the composite can affect its total load capacity. 
- The use of scarf joints in glulam of paricá showed similar results in relation to that observed in glulam of paricá without scarf joints, suggesting that due to their practicality and performance, they can be used in the manufacture of this product;

- Scarf joints with slope of 1:12 can be used as a longitudinal joint for structural purposes in paricá timbers.

\section{REFERENCES}

ALMEIDA, D.H.; SCALIANTE, R.M.; CAVALHEIRO, R.S.; MACEDO, L.B.; CHRISTOFORO, A.L.; MACEDO, A.N.; CALIL JUNIOR, A.; LAHR, F.A.R. Combinação madeira-adesivo-impermeabilizante em MLC. Madeira, São Carlos, v.12, n. 31, 2011.

ALMEIDA, D. H., SCALIANTE, R.M.; MACEDO, L.B.; MACEDO, A.N.; CALIL JUNIOR, C. Madeira laminada colada (MLC) da espécie paricá. Madeira, São Carlos, v.12, n. 30. 2011.

AMERICAN SOCIETY FOR TESTING AND MATERIALS, ASTM D4761-13, Standard Test Methods for Mechanical Properties of Lumber and Wood-Base Structural Material, West Conshohocken, PA, 2013.

ARCISZEWSKA-KĘDZIOR, A.; KUNECKÝ, J.; HASNÍKOVÁ, H. Mechanical response of a lap scarf joint with inclined faces and wooden dowels under combined loading. Journal of heritage conservation, n. 46, $p$. 80-88, 2016. doi:10.17425/WK46WOODEN.

ASSOCIAÇÃO BRASILEIRA DE NORMAS TÉCNICAS, ABNT, NBR 7190 - Projeto de estruturas de madeiras, Rio de Janeiro, 1997, 107p.

CUNHA, A.B.; MATOS, J. L.M. Avaliação da rigidez de vigas estruturais de madeira laminada colada unidas por adesivo poliuretano. Cerne, Lavras, v.17, n. 4, p. 593-600, 2011.

DEUTSCHES INSTITUT FÜR NORMUNG. DIN - 68140: Wood Finger-Jointing. Berlin: DIN, 1971.

DAJBYCH, O.; HERÁK, D.; SEDLÁCEK, A.; GÜRDIL, G. Determination of loading capacity depending on bevel angle of the wooden bonded scarf joint. Research in agricultural engineering, Praha, v. 56, n. 4, 2010.

HERÁK, D. MÜLLER, M.; CHOTEBORSKÝ, R.; DAJBYCH, O. Loading capacity determination of the wooden scarf joint. Research in agricultural engineering, Praha, v. 2, n. 55, p. 76-83, 2009.

Instituto Brasileiro de Árvores - IBA: Industria Brasileira de Árvores. Relatório 2017. São Paulo, SP, 2017. 78p. 2017.

KIMIAEIFAR, A.; TOFT, H.; LUND, E.; THOMSEN, O.T.; SØRENSEN, J.D. Reliability analysis of adhesive bonded scarf joints. Engineering Structures, v. 35, p. 281-297, 2012. doi:10.1016/j.engstruct.2011.11.013.

MELO, R.R.; DEL MENEZZI, C.H.S.; PAVAN, B.E.; RODOLFO JÚNIOR, F. Rotary peeling yield of Schizolobium amazonicum (Leguminosae - Caesalpinioideae). Acta Amazonica. v. 44, n.3, p. 315-320, 2014. http://dx.doi.org/10.1590/1809-4392201302926 .

NASCIMENTO, A.M.; DELLA LUCIA, R.M.; VITAL, B.R. Colagem de emendas biseladas em madeiras de Pinus sp e Eucalyptus citriodora. Floresta e Ambiente. Seropédia, v.8, n.1, p.44-51, 2001.

ROSA, T. O.; TEREZO, R.F.; MASCIA, N.T.; RIGHEZ, J.L.B. Glued laminated timber of paricá reinforced with synthetic fibers. Floresta, Curitiba, v. 49, n. 3. Jul/2019.

SILVA, M.G. et al. Estudo anatômico e físico da madeira de Schizolobium parahyba var. amazonicum proveniente de povoamentos nativos da Amazônia Oriental. Scientia Forestalis, Piracicaba, v. 44, n. 110, p. 293-301, jun. 2016. dx.doi.org/10.18671/scifor.v44n110.02.

TEREZO, R.F.; SZÜCS, C.A. Análise de desempenho de vigas em madeira laminada colada de paricá (Schizolobium amazonicum Huber ex Ducke), Scientia Forestalis, Piracicaba, v. 38, n. 87. p.471-480, set.2010.

TEREZO, R.F. et al. Propriedades da Madeira de parica em diferentes idades para uso estrutural. Ciência da Madeira, Belo Horizonte, v. 6. n. 3, p. 244-253, 2015. 